\title{
Ehlers-Danlos syndrome, hypermobility type
}

INSERM

\section{Source}

INSERM. (1999). Orphanet: an online rare disease and orphan drug data base. EhlersDanlos syndrome, hypermobility type. ORPHA:285

Ehlers-Danlos syndrome, hypermobility type (HT-EDS) is the most frequent form of EDS (see this term), a group of hereditary connective tissue diseases, and is characterized by joint hyperlaxity, mild skin hyperextensibility, tissue fragility and extra-musculoskeletal manifestations. 